\title{
A public health enhanced surveillance system for a mass gathering event
}

\author{
C Huot ${ }^{1 \star}$, A Paradis², K Hammond-Collins ${ }^{3}$, MA Bélair ${ }^{4}$, J Villeneuve 5 , N Brousseau', \\ I Goupil-Sormany ${ }^{1,2}$, J Riffon ${ }^{1}$
}

\begin{abstract}
Background: From June 7 to June 9, 2018, a G7 Summit was held in the Canadian province of Quebec. This international political mass gathering event posed a number of potential risks to public health.
\end{abstract}

Objective: To assess three additional monitoring strategies to detect public health threats during a mass gathering event.

Intervention: In addition to routine public health monitoring, a partnership was created and three monitoring strategies were put in place three days before, during and six days after the G7 event: the analysis of data on the presenting complaint and discharge diagnosis from 11 emergency departments in the area using the logiciel Early Aberration Reporting System; the daily polling of key health partners with an online questionnaire; and the analysis of calls to Info-Santé, a government-run telephone consultation service for the public regarding health and social issues.

Results: Emergency room data produced 78 alerts from the presenting complaints and 39 alerts from the discharge diagnoses. Of these 117 alerts, two were investigated (one in the respiratory and one in the neurological-muscular categories) and no other interventions were required. With a few exceptions, all of the health partners completed the online survey each day and no signal of concern was generated. Compared with historical data, no increase or differences in calls to Info-Santé were detected during the monitoring period.

Conclusion: The three additional monitoring strategies developed to detect events of public health importance during the 2018 G7 Summit in Quebec were successful in gathering timely data for analysis. Close collaboration and good participation from the different partners were essential to this project. However, because no public health event occurred, it was not possible to determine whether the enhanced surveillance system had sufficient speed and sensitivity for timely detection and response.
This work is licensed under a Creative Commons Attribution 4.0 International License.

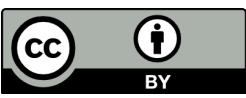

Affiliations

${ }^{1}$ Direction de santé publique du Centre intégré universitaire de santé et de services sociaux de la Capitale-Nationale, Québec, QC

2 Département de médecine sociale et préventive, Université Laval, Québec, QC

${ }^{3}$ Centre for Food-borne, Environmental and Zoonotic Infecious Diseases, Public Health Agency of Canada, Ottawa, ON

${ }^{4}$ Centre for Emergency Preparedness and Response, Public Health Agency of Canada, Whitehorse, YK

${ }^{5}$ Institut national de santé publique du Québec, Québec, QC

\section{*Correspondence:}

caroline.huot@inspq.qc.ca

Suggested citation: Huot C, Paradis A, Hammond-Collins K, Bélair MA, Villeneuve J, Brousseau N, Goupil-Sormany I, Riffon J. A public health enhanced surveillance system for a mass gathering event. Can Commun Dis Rep 2019;45(7/8):212-24. https://doi.org/10.14745/ccdr.v45i78a05

Keywords: mass gathering event, surveillance, syndromic surveillance, public health, epidemiology

\section{Introduction}

From June 7 to June 9, 2018, the prime minister of Canada hosted a G7 Summit in La Malbaie and Québec, Quebec (1). Seven internationally protected persons and their delegations (approximately 3,200 people), 3,200 journalists, thousands of demonstrators, 1,000 to 2,000 police officers, 1,000 service members from the Canadian Armed Forces and approximately
12,000 people from a number of non-G7 countries invited as part of the Outreach Program were expected to attend.

In preparation for this event, experts in emergency management were consulted, and the literature (2-9), including lessons learned from the Summit of the Americas in 2001 (10), was reviewed. A number of monitoring initiatives previously applied 
during sporting (3,11-19), religious $(5,20,21)$ and artistic events $(22,23)$ have been described previously. However, there was less detailed information available about surveillance during political events, especially those that are at risk for violent demonstrations or acts of terrorism $(24,25)$.

In advance of the event, a number of potential public health threats were identified and prioritized for monitoring: rapid spread of certain infectious diseases; violence associated with demonstrations and use of crowd-control agents; potential for chemical, biological, radiological, nuclear or explosive (CBRNE) terrorist threats; and presence of suspicious packages (26). Although the probability of these threats was considered low $(11-16,27)$, an enhanced surveillance system was needed to quickly detect potential public health threats (28-31), as well as a rapid intervention plan for each of these threats.

Routine public health surveillance in Quebec relies on the mandatory reporting of notifiable diseases by physicians and laboratories, and on the passive reporting of perceived or real public health threats by various partners, including clinicians, government departments and local municipalities (32). However, these routine surveillance activities lacked the necessary sensitivity and timeliness to rapidly detect and respond to priority public health threats during the G7 Summit (33). To address this, the Direction de santé publique (DSPublique) of the Centre intégré universitaire de santé et de services sociaux de la Capitale-Nationale (Public Health Department of the Nationale Capital Integrated University Health and Social Services Centre) developed an enhanced surveillance system that included activities for the period from June 4 to June 15, 2018 (three days before, three days during and six days after the event). The goal of the enhanced surveillance system was to develop a surveillance capacity that met the goals of early detection and acceptability to all participating partners.

The purpose of this article is to describe the development and outcome of three monitoring strategies that were part of the enhanced surveillance system during the 2018 G7 Summit, and to consider the implications of these strategies for public health surveillance during future mass gathering events.

\section{Establishing partnerships}

Approximately six months before the event, a DSPublique project team began the development of an enhanced surveillance system. All of the region's emergency departments (ED) already had in place electronic records for both presenting complaints (those given by patients to the triage nurses when they came into the ED) and medical discharge diagnoses (those given by a physician when the patient left the ED). Not all these data are usually available to the DSPublique, and they had not been previously used for public health surveillance. The EDs of six university hospital centres and five regional hospital centres within the event perimeter or nearby were invited to collaborate for this event. To ensure access to these data, additional partners from other Integrated University Health and Social Services Centre departments collaborated with the DSPublique project team.

To receive daily reports from key partners, five organizations likely to detect the targeted threats early were approached: the Centre antipoison du Québec (Quebéc Poison Control Centre); the region's ambulance services; the Laboratoire de santé publique du Québec (Quebec Public Health Laboratory); and the Bureau du coroner (Quebec Coroner's Office). Info-Santé (a public telephone consultation service for health and social issues) was a key partner that provided daily reports and contributed data for enhanced surveillance. Three temporary clinics were set up for the event and also submitted daily reports.

In addition to the partners who directly contributed to the enhanced surveillance system, the region's clinicians were informed of the project's progress stage-by-stage through the emergency management structure, which was put on alert for the event. The Public Health Agency of Canada provided support, deploying two field epidemiologists for planning, analyzing data and producing reports. All the enhanced monitoring activities were timed to allow for rapid analysis and dissemination of results, decision-making and response. A daily report summarizing the results was prepared and distributed to the DSPublique, partners and decision-makers. Two versions (short and detailed), adapted to the target audiences, were available.

\section{Enhanced monitoring activities}

To enhance the sensitivity and timeliness of the surveillance system, while ensuring it remained acceptable to all partners, the following three monitoring activities were added to Notifiable Disease reporting and passive reporting for the period from June 4 to June 15, 2018:

- Monitoring trends in presenting complaints and discharge diagnoses at ED

- Requesting daily reports from key partners

- Monitoring trends in calls to Info-Santé

\section{Monitoring trends from emergency departments}

For the ED electronic data, presenting complaints were recorded by the triage nurse following a patients' arrival, and medical discharge diagnoses were recorded when the patient was ready to leave the ED. All univserity hospital patients were identified with a unique identifier number. These data were available the day after the visit. Electronic record data from all ED visits in the area surrounding the G7 Summit were incorporated into the enhanced surveillance system. This approach was acceptable to clinical partners because these data were already available 
for other purposes. However, it did create a slight increase in workload, as reminders were sent if there were entry delays.

The discharge diagnoses were identified according to the International Classification of Diseases, $10^{\text {th }}$ revision (ICD-10) as per the Quebec guidelines (34). Selected presenting complaints and discharge diagnoses were sorted and analyzed by category (see Appendices 1 and 2). A few discharge diagnoses were also analyzed individually; these included either a notifiable disease or a diagnosis for which a public health response may be indicated for a single case, such as measles (see last column in Appendix 2). Two clinicians-one specializing in CBRNE emergencies and the other in clinical toxicology—validated the choices.

The number of cases in each category was analyzed using the Centers for Disease Control and Prevention's Early Aberration Reporting System (35) software, which detects alerts or aberrations in the number of cases based on short-term historical data (ten days). All the generated alerts were compared with historic data for the period of April to July 2013-2017. A daily analysis of the previous day's data was conducted, by emergency department and for all emergency departments combined. Age group, municipality of the cases and details on the presenting complaints and diagnoses were used when available. A team evaluation and decision were made regarding whether or not to further investigate each alert that was generated.

\section{Daily reports from key partners}

Key partners included Quebéc's Poison Control Centre, the region's ambulance services, the Quebec Public Health Laboratory, the Coroner's Office, Info-Santé and three temporary clinics. A short, three-question online questionnaire (Voxco Inc. platform) (36) was developed and sent to respondents from partner organizations on a daily basis (before, during and after the event) regarding infectious or environmental health threats. Questionnaires were completed by 10 am regarding information from the previous day.

\section{Monitoring trends for calls to Info-Santé}

Electronic data on the reasons for calling Info-Santé were already available to the DSPublique, but had not previously been used for surveillance. The most relevant reasons for calling were selected based on the priority threats (Table 1). These reasons were sorted into categories for enhanced surveillance. In each category, the number and percentage of calls were analyzed on a daily basis to detect any increase or change compared with historical data.
Table 1: Monitored reasons for calling Info-Santé by category

\begin{tabular}{|l|l|}
\multicolumn{1}{|c|}{ Category } & \multicolumn{1}{c|}{ Reasons for calling } \\
\hline Cardiovascular & $\begin{array}{l}\text { Cardiovascular system manifestations or } \\
\text { symptoms }\end{array}$ \\
\hline \multirow{2}{*}{$\begin{array}{l}\text { CBRNE/physical/ } \\
\text { environmental }\end{array}$} & Extreme heat \\
\cline { 2 - 2 } & Intoxications \\
\cline { 2 - 2 } & Large events \\
\cline { 2 - 2 } & Environmental health \\
\hline Cutaneous/lymphatic & Skin and tissue manifestations or symptoms \\
\hline \multirow{2}{*}{ Extreme } & Avian influenza (bird flu) \\
\cline { 2 - 2 } & Ebola virus \\
\hline Gastrointestinal & $\begin{array}{l}\text { Gastrointestinal system manifestations or } \\
\text { symptoms }\end{array}$ \\
\hline Infectious & Infectious and parasitic diseases \\
\cline { 2 - 2 } & Thermoregulation \\
\hline Neurological/muscular & Nervous system manifestations or symptoms \\
\hline \multirow{2}{*}{$\begin{array}{l}\text { Ophthalmological/ } \\
\text { otorhinolaryngological }\end{array}$} & Ophthalmic manifestations or symptoms \\
\hline Respiratory & Influenza-like illness \\
\cline { 2 - 2 } & Respiratory problems excluding the flu \\
\hline
\end{tabular}

Abbreviation: CBRNE, chemical, biological, radiological, nuclear or explosive

\section{Results}

\section{Emergency department data}

During the monitoring period, data were available for both the presenting complaints and the discharge diagnoses. No presenting complaint data were missing. Overall, 27\% of diagnosis data were missing during the entire monitoring period, which extended from June 4 to 15. During the G7 Summit (June 7 to 9), however, only $23 \%$ of diagnosis data were missing. These missing data were due to patients leaving the ED before a diagnosis was made and delays in the entry of diagnoses into the electronic record.

Emergency department data produced 78 alerts for the presenting complaint categories and generated 39 alerts in the various diagnosis categories. Among these 117 alerts, two were investigated (one for respiratory category and one for neurological-muscular category). No other intervention was required. Table 2 summarizes the number of alerts per category.

\section{Daily reports and Info-Santé}

With a few exceptions, all of the partners completed the survey every day and few reminders were required. One of the three temporary clinics reported two cases of gastroenteritis. Ambulance services reported one case of opioid intoxication. Given that these reports did not exceed the expected frequency and there were no related health threats, none of these reports was investigated. 
Table 2: Number of alerts by presenting complaint and discharge diagnosis category from 11 emergency departments in the La Malbaie/Québec region, June 4-15, 2018

\begin{tabular}{|l|r|r|}
\multirow{2}{*}{ Category } & \multicolumn{2}{|c|}{ Number of alerts } \\
\cline { 2 - 3 } & $\begin{array}{c}\text { Presenting } \\
\text { complaints }\end{array}$ & $\begin{array}{c}\text { Discharge } \\
\text { diagnosis }\end{array}$ \\
\hline Cardiovascular & 5 & 3 \\
\hline CBRNE/physical/environmental & 6 & 4 \\
\hline Cutaneous/lymphatic & 6 & 4 \\
\hline Fever & 9 & $\mathrm{n} / \mathrm{a}$ \\
\hline Gastrointestinal & 9 & 0 \\
\hline Hemorrhagic & 8 & 6 \\
\hline Infectious & $\mathrm{n} / \mathrm{a}$ & 5 \\
\hline Opioid intoxication & $\mathrm{n} / \mathrm{a}$ & 0 \\
\hline Neurological/muscular & 8 & 8 \\
\hline Ophthalmic/Otorhinolaryngological & 9 & 4 \\
\hline Respiratory & 5 & 2 \\
\hline Systemic/dehydration & 13 & 3 \\
\hline TOTAL & 78 & 39 \\
\hline
\end{tabular}

Abbreviations: CBRNE, chemical, biological, radiological, nuclear or explosive; $n / a$; not applicable

In analyzing the reasons for calls to Info-Santé, neither increases nor differences were detected during the monitoring period in comparison with historical data.

\section{Discussion}

A three-pronged enhanced surveillance system, developed to detect events of public health importance during the 2018 G7 Summit in Quebec, was successful in gathering timely data for analysis. Most alerts were generated from the analysis of ED data. The use of historical data made it possible to limit the number of alerts for which an investigation was needed. The use of these data appeared to result in high sensitivity but low specificity.

A strength of this enhanced surveillance system was the close collaboration with a number of different partners. This collaboration was essential to the development of this enhanced surveillance system. The three additional monitoring strategies exhibited a high level of participation by the partners. This was likely because partners understood the importance of the additional monitoring and because only minimal additional time was required by participants. Thus, most data requested from the partners were received in a timely manner.
This work identified the feasibility of our enhanced surveillance system and could inform future public health preparedness for mass gathering events. However, because no public health event occurred, it was not possible to determine whether the enhanced surveillance system had sufficient speed and sensitivity for timely detection and response.

\section{Conclusion}

Three additional monitoring strategies developed to detect events of public health importance during the 2018 G7 Summit in Quebec were successful in gathering timely data for analysis. However, further assessment of speed and sensitivity is needed if applied to a future public health surveillance strategy of a mass gathering event.

\section{Authors' statement}

HC - Conceptualization, methodology, intervention, analysis and interpretation of data, article writing

AP - Conceptualization, methodology, intervention, analysis and interpretation of data, article review

$\mathrm{KHC}$ - Intervention, analysis and interpretation of data, article review

$M A B$ - Analysis and interpretation of data, article review

JV - Conceptualization, methodology, article review

NB - Intervention, analysis and interpretation of data, article review

IGS - Conceptualization, resources, article review JR - Intervention, analysis and interpretation of data, article review

\section{Conflict of interest}

None.

\section{Acknowledgements}

The authors would like to acknowledge the assistance of the following colleagues: FW Tremblay, M Mercier, F Desbiens, N Beaulieu, I Beaulieu, C Thibault, A Paradis, N Allain-Boulé, M Beauregard, A Maurice, N Thériault, J Lizotte, S Gaudreault, J Larocque, S Blais, D Martineau, V Tremblay, R Dion, È Pilon, and M St-Onge.

\section{Funding}

This work was supported by the Centre intégré universitaire de santé et de services sociaux de la Capitale-Nationale and the Public Health Agency of Canada. 


\section{References}

1. Présidence canadienne du G7 de 2018. Présidence canadienne du G7 de 2018. 2018. https://international. gc.ca/world-monde/international_relations-relations_ internationales/g7/index.aspx?lang=fra\#a3

2. Kaiser R, Coulombier D. Epidemic intelligence during mass gatherings. Euro Surveill 2006 Dec;11(12):E061221.3. DOI PubMed

3. Elliot AJ, Hughes HE, Hughes TC, Locker TE, Shannon T, Heyworth J, Wapling A, Catchpole M, Ibbotson S, McCloskey $B$, Smith GE. Establishing an emergency department syndromic surveillance system to support the London 2012 Olympic and Paralympic Games. Emerg Med J 2012 Dec;29(12):954-60. DOl PubMed

4. Abubakar I, Gautret P, Brunette GW, Blumberg L, Johnson D, Poumerol G, Memish ZA, Barbeschi M, Khan AS. Global perspectives for prevention of infectious diseases associated with mass gatherings. Lancet Infect Dis 2012 Jan;12(1):6674. DOI PubMed

5. Memish ZA, Zumla A, Alhakeem RF, Assiri A, Turkestani A, Al Harby KD, Alyemni M, Dhafar K, Gautret P, Barbeschi M, McCloskey B, Heymann D, Al Rabeeah AA, Al-Tawfiq JA. Hajj: infectious disease surveillance and control. Lancet 2014 Jun;383(9934):2073-82. DOl PubMed

6. Sun X, Keim M, He Y, Mahany M, Yuan Z. Reducing the risk of public health emergencies for the world's largest mass gathering: 2010 World Exposition, Shanghai China. Disaster Health 2013 Jan;1(1):21-9. DOI PubMed

7. Menezes RG, Hussain SA, Rameez MA, Kharoshah MA, Madadin M, Anwar N, Senthilkumaran S. Chemical crowd control agents. Med Leg J 2016 Mar;84(1):22-5. DOI PubMed

8. Heggie TW. Traveling to Canada for the Vancouver 2010 Winter Olympic and Paralympic Games. Travel Med Infect Dis 2009 Jul;7(4):207-11. DOl PubMed

9. Ortiz I, Burke S, Berrada M, Cortes H. World Protests 20062013. Initiative for Policy Dialogue and Friedrich-EbertStiftung New York Working Paper 2013 (Accessed 201809-24). http://policydialogue.org/files/publications/papers/ World_Protests_2006-2013-Complete_and_Final_4282014. pdf

10. Rhainds M, Gaulin C, Goupil-Sormany I. Le Sommet des Amériques et la santé publique : plan de préparation et d'intervention - Résumé de présentation. BISE (Bulletin d'information en santé environnementale). juin 2002;13(3, supplément):3. http://collections.banq.qc.ca/ ark:/52327/bs26007

11. Kajita E, Luarca MZ, Wu H, Hwang B, Mascola L. Harnessing Syndromic Surveillance Emergency Department Data to Monitor Health Impacts During the 2015 Special Olympics World Games. Public Health Rep 2017 Jul/Aug;132(1_suppl Suppl 1):99S-105S. DOI PubMed
12. McCloskey B, Endericks $T$, Catchpole $M$, Zambon $M$, McLauchlin J, Shetty N, Manuel R, Turbitt D, Smith G, Crook $P$, Severi E, Jones J, Ibbotson S, Marshall R, Smallwood CA, Isla N, Memish ZA, Al-Rabeeah AA, Barbeschi M, Heymann DL, Zumla A. London 2012 Olympic and Paralympic Games: public health surveillance and epidemiology. Lancet 2014 Jun;383(9934):2083-9. DOI PubMed

13. Chan E, Hohenadel K, Lee B, Helferty M, Harris JR, Macdonald L, Badiani T. Public health surveillance for the Toronto 2015 Pan/Parapan American Games. Can Commun Dis Rep 2017 Jul;43(7):156-63. DOI PubMed

14. Jorm LR, Thackway SV, Churches TR, Hills MW. Watching the Games: public health surveillance for the Sydney 2000 Olympic Games. J Epidemiol Community Health 2003 Feb;57(2):102-8. DOl PubMed

15. Tsouros AD, Efstathiou PA. Mass gatherings and public health: the experience of the Athens 2004 Olympic Games. World Health Organization Regional Office for Europe. WHO 2007 (Accessed 2018-09-24). http://www.euro.who.int/ data/assets/pdf_file/0009/98415/E90712.pdf

16. Dapeng J, Ljungqvist A, Troedsson $\mathrm{H}$. The Health Legacy of the 2008 Beijing Olympic Games: Successes and Recommendations. World Health Organization Regional Office for the Western Pacific. Geneva (CH): WHO 2010 (Accessed 2018-09-24). https://stillmed.olympic.org/ Documents/Commissions_PDFfiles/Medical_commission/ The_Health_Legacy_of_the_2008_Beijing_Olympic_Games. pdf

17. Takla A, Velasco E, Benzler J. The FIFA Women's World Cup in Germany 2011--a practical example for tailoring an event-specific enhanced infectious disease surveillance system. BMC Public Health 2012 Jul;12:576. DOI PubMed

18. Todkill D, Hughes HE, Elliot AJ, Morbey RA, Edeghere $O$, Harcourt S, Hughes T, Endericks T, McCloskey B, Catchpole M, Ibbotson S, Smith G. An Observational Study Using English Syndromic Surveillance Data Collected During the 2012 London Olympics - What did Syndromic Surveillance Show and What Can We Learn for Future Mass-gathering Events? Prehosp Disaster Med 2016 Dec;31(6):628-34. DOI PubMed

19. Severi E, Heinsbroek E, Watson C, Catchpole M; HPA Olympics Surveillance Work Group. Infectious disease surveillance for the London 2012 Olympic and Paralympic Games. Euro Surveill 2012 Aug;17(31):20232. DOI PubMed

20. Alqahtani AS, BinDhim NF, Tashani M, Willaby HW, Wiley $K E$, Heywood AE, Booy R, Rashid H. Pilot use of a novel smartphone application to track traveller health behaviour and collect infectious disease data during a mass gathering: hajj pilgrimage 2014. J Epidemiol Glob Health 2016 Sep;6(3):147-55. DOI PubMed

21. Alotaibi BM, Yezli S, Bin Saeed AA, Turkestani A, Alawam $A H$, Bieh KL. Strengthening health security at the Hajj mass gatherings: characteristics of the infectious diseases surveillance systems operational during the 2015 Hajj. J Travel Med 2017 May;24(3): DOI PubMed 
22. Polkinghorne BG, Massey PD, Durrheim DN, Byrnes T, Maclntyre CR. Prevention and surveillance of public health risks during extended mass gatherings in rural areas: the experience of the Tamworth Country Music Festival, Australia. Public Health 2013 Jan;127(1):32-8. DOI PubMed

23. Hoy D, Saketa S, Maraka RR, Sio A, Wanyeki I, Frison P, Ogaoga D, Iniakawala D, Joshua C, Duituturaga S, Lepers C, Roth A, White P, Souares Y. Enhanced syndromic surveillance for mass gatherings in the Pacific: a case study of the 11th Festival of Pacific Arts in Solomon Islands, 2012. West Pac Surveill Response. 2016;7:15-20. https://read.qxmd.com/ journal/47699/3

24. Hick JL, Frascone RJ, Grimm K, Hillman M, Griffith J, Hogan M, Trotsky-Sirr R, Braun J. Health and medical preparedness and response to the 2008 Republican National Convention. Disaster Med Public Health Prep 2009 Dec;3(4):224-32. DOI PubMed

25. Sugishita $Y$, Ohkusa $Y$, Sugawara T, Shimatani N, Nadaoka Y, Kamiya N, Yasui Y, Taniguchi K, Okabe N. Enhanced Syndromic Surveillance for the Fourth Japan-China-South Korea Trilateral Summit 2011. J Bioterror Biodef 2013;4:1-7. DOI

26. Public Health Agency of Canada. Biological Threats. Ottawa (ON): PHAC 2004 (Accessed 2018-07-01). http://www. phac-aspc.gc.ca/ep-mu/faq-eng.php

27. Fleischauer AT, Gaines J. Enhancing Surveillance for Mass Gatherings: The Role of Syndromic Surveillance. Public Health Rep 2017 Jul/Aug;132(1_suppl Suppl 1):95S-8S. DOI PubMed
28. World Health Organization. Public health for mass gatherings: key considerations. Geneva (CH): WHO; 2015. www.who.int/ihr/publications/WHO_HSE_GCR_2015.5/en/

29. Elliot AJ, Morbey RA, Hughes HE, Harcourt SE, Smith S, Loveridge P, Edeghere O, Ibbotson S, McCloskey B, Catchpole M, Smith GE. Syndromic surveillance - a public health legacy of the London 2012 Olympic and Paralympic Games. Public Health 2013 Aug;127(8):777-81. DOI PubMed

30. Berry AC. Syndromic surveillance and its utilisation for mass gatherings. Epidemiol Infect 2018 Jun;1-3:1-3. DOI PubMed

31. Thackway S, Churches T, Fizzell J, Muscatello D, Armstrong $P$. Should cities hosting mass gatherings invest in public health surveillance and planning? Reflections from a decade of mass gatherings in Sydney, Australia. BMC Public Health 2009 Sep;9:324. DOI PubMed

32. LégisQuébec. Loi sur la santé publique. 2001 (Accessed 2017-07-01). http://legisquebec.gouv.qc.ca/fr/ShowDoc/ $\mathrm{cs} / \mathrm{S}-2.2$

33. Lee LM, Steven M, Teutsch SM, Thacker SB, St-Louis ME. Principles and Practice of Public Health Surveillance. Oxford University Press; 2010. DOI

34. Ministère de la Santé et des Services sociaux, Direction générale des services de santé et médecine universitaire. Cadre normatif pour le système d'information de gestion des urgences (SIGDU). 2009. http://numerique.banq.qc.ca/ patrimoine/details/52327/49642

35. Centers for Disease Control and Prevention. Surveillance Resource Center (Accessed 2019-01-21). www.cdc.gov/ surveillancepractice/index.html

36. Voxco Inc. Logiciel d'enquête flexible. www.voxco.com/fr/ 
Appendix 1: Monitored presenting complaints from emergency departments, by category

\section{Category}

Cardiovascular

CBRNE/physical/environmental

Cutaneous/lymphatic

Hemorrhagic

Neurological/muscular

Ophthalmological/

Otorhinolaryngological

\section{Presenting complaint}

Cardiac arrest (non-traumatic)

Chest pain-cardiac features

Noxious inhalation

Chemical exposure

Intoxication

Exposure to communicable disease

Reddened hot limb

Neck swelling/pain

Groin pain/mass

Pruritus

Rash

Localized swelling/redness

Other skin conditions

Lumps, bumps, calluses

Burn

Fever

\section{Diarrhea}

Nausea/vomiting

Blood in stool/melena

Jaundice

Abdominal pain

Diarrhea and fever

Epistaxis

Vomiting blood

Hematuria

Spontaneous bruising

Difficulty swallowing/dysphagia

Altered level of consciousness

Confusion

Seizure

Gait disturbance/ataxia

Extremity weakness/symptoms of cerebrovascular accident

Headache

Diplopia

Sore throat

Chemical exposure, eye

Visual disturbance

Red eye, discharge

Photophobia

Eye pain

Eye trauma 
Appendix 1: Monitored presenting complaints from emergency departments, by category (continued)

\begin{tabular}{|c|c|}
\hline Category & Presenting complaint \\
\hline \multirow[t]{9}{*}{ Respiratory } & Symptoms of upper respiratory tract infection \\
\hline & Chest pain-non-cardiac features \\
\hline & Dyspnea \\
\hline & Respiratory arrest \\
\hline & Cough/congestion \\
\hline & Hemoptysis \\
\hline & Stridor \\
\hline & Wheezing-no other complaints \\
\hline & Cough and fever/Influenza-like illness \\
\hline \multirow[t]{4}{*}{ Systemic/dehydration } & General weakness \\
\hline & Syncope/pre-syncope \\
\hline & Oliguria \\
\hline & Cyanosis \\
\hline
\end{tabular}


Appendix 2: Monitored discharge diagnoses with ICD-10 code from emergency departments, by category ${ }^{\mathrm{a}}$

\begin{tabular}{|c|c|c|c|}
\hline Category & $\begin{array}{l}\text { ICD-10 } \\
\text { code }\end{array}$ & ICD-10 diagnosis & $\begin{array}{l}\text { Individual } \\
\text { analysis } \\
\text { done (Y/N) }\end{array}$ \\
\hline \multirow[t]{11}{*}{ Cardiovascular } & 120.0 & Unstable angina & $\mathrm{N}$ \\
\hline & 120.9 & Angina pectoris & $\mathrm{N}$ \\
\hline & 121.9 & Acute myocardial infarction & $\mathrm{N}$ \\
\hline & 124.9 & Acute ischemic heart disease, acute coronary syndrome (ACS) & $\mathrm{N}$ \\
\hline & 146.9 & Cardiac arrest & $\mathrm{N}$ \\
\hline & 195.9 & Hypotension & $\mathrm{N}$ \\
\hline & R00.1 & Bradycardia & $\mathrm{N}$ \\
\hline & $\mathrm{R} 07.2$ & Chest pain of unknown cause & $\mathrm{N}$ \\
\hline & R07.3 & Anterior chest-wall pain & $\mathrm{N}$ \\
\hline & R07.4 & Chest pain & $\mathrm{N}$ \\
\hline & R57.0 & Cardiogenic shock & $\mathrm{N}$ \\
\hline \multirow{17}{*}{$\begin{array}{l}\text { CBRNE/physical/ } \\
\text { environmental }\end{array}$} & J68.9 & Inhalation of toxic products & Y \\
\hline & T59.9 & Toxic effect: gases, fumes and vapours & $\mathrm{Y}$ \\
\hline & T62.9 & Noxious substance eaten as food & Y \\
\hline & T67.0 & Heatstroke and sunstroke & $\mathrm{Y}$ \\
\hline & T52.9 & Toxic effect: organic solvent & $\mathrm{N}$ \\
\hline & T54.9 & Toxic effect: corrosive substance & $\mathrm{N}$ \\
\hline & T58 & Toxic effect of carbon monoxide & $\mathrm{N}$ \\
\hline & T60.9 & Toxic effect: pesticide & $\mathrm{N}$ \\
\hline & T65.9 & Toxic effect: unspecified substance & $\mathrm{N}$ \\
\hline & T66 & Effects of radiation & $\mathrm{N}$ \\
\hline & T67.9 & Effect of heat and light & $\mathrm{N}$ \\
\hline & T71 & Asphyxiation & $\mathrm{N}$ \\
\hline & Y14 & $\begin{array}{l}\text { Poisoning by and exposure to other and unspecified drugs, medicaments and biological } \\
\text { substances, undetermined intent }\end{array}$ & $\mathrm{N}$ \\
\hline & Y17 & Poisoning by and exposure to other gases and vapours, undetermined intent & $\mathrm{N}$ \\
\hline & Y25 & Contact with explosive material, undetermined intent & $\mathrm{N}$ \\
\hline & Z20.9 & Contact with and exposure to unspecified communicable disease & $\mathrm{N}$ \\
\hline & Z29.9 & Prophylactic measure & $\mathrm{N}$ \\
\hline \multirow[t]{15}{*}{ Cutaneous/lymphatic } & B05.9 & Measles & $\mathrm{Y}$ \\
\hline & B09 & Viral exanthema & $\mathrm{Y}$ \\
\hline & L02.9 & Cutaneous abscess, furuncle and carbuncle & $\mathbf{Y}$ \\
\hline & 188.9 & Nonspecific lymphadenitis & $\mathrm{N}$ \\
\hline & 189.1 & Lymphangitis & $\mathrm{N}$ \\
\hline & L03.9 & Cellulitis & $\mathrm{N}$ \\
\hline & L13.9 & Bullous disorder & $\mathrm{N}$ \\
\hline & L25.9 & Unspecified contact dermatitis & $\mathrm{N}$ \\
\hline & L29.9 & Pruritus & $\mathrm{N}$ \\
\hline & L50.9 & Urticaria & $\mathrm{N}$ \\
\hline & L51.9 & Erythema multiforme & $\mathrm{N}$ \\
\hline & L72.9 & Cyst of skin & $\mathrm{N}$ \\
\hline & L97 & Ulcer of lower limb, diabetic foot ulcer & $\mathrm{N}$ \\
\hline & L98.9 & Disorder of skin and subcutaneous tissue & $\mathrm{N}$ \\
\hline & M72.69 & Necrotizing fasciitis & $\mathrm{N}$ \\
\hline
\end{tabular}


Appendix 2: Monitored discharge diagnoses with ICD-10 code from emergency departments, by category ${ }^{\mathrm{a}}$ (continued)

\begin{tabular}{|c|c|c|c|}
\hline Category & $\begin{array}{l}\text { ICD-10 } \\
\text { code }\end{array}$ & CD-10 diagnosis & $\begin{array}{c}\text { Individual } \\
\text { analysis } \\
\text { done }(\mathrm{Y} / \mathrm{N})\end{array}$ \\
\hline \multirow{8}{*}{$\begin{array}{l}\text { Cutaneous/lymphatic } \\
\text { (continued) }\end{array}$} & R21 & Rash & $\mathrm{N}$ \\
\hline & R22.9 & Localized swelling, mass and lump & $\mathrm{N}$ \\
\hline & R59.9 & Enlarged lymph nodes & $\mathrm{N}$ \\
\hline & R60.0 & Localized edema & $\mathrm{N}$ \\
\hline & T29.0 & Burns of multiple regions & $\mathrm{N}$ \\
\hline & T30.1 & Burn of first degree & $\mathrm{N}$ \\
\hline & $\mathrm{T} 30.2$ & Burn of second degree & $\mathrm{N}$ \\
\hline & T30.3 & Burn of third degree & $\mathrm{N}$ \\
\hline \multirow[t]{14}{*}{ Gastrointestinal } & A05.9 & Bacterial foodborne intoxication & $\mathbf{Y}$ \\
\hline & A09.9 & Gastroenteritis & $\mathbf{Y}$ \\
\hline & B19.9 & Viral hepatitis & $\mathbf{Y}$ \\
\hline & K29.7 & Gastritis & $\mathrm{N}$ \\
\hline & K29.9 & Gastroduodenitis & $\mathrm{N}$ \\
\hline & K51.9 & Ulcerative colitis & $\mathrm{N}$ \\
\hline & $\mathrm{K} 56.7$ & lleus & $\mathrm{N}$ \\
\hline & K65.0 & Acute peritonitis & $\mathrm{N}$ \\
\hline & K72.9 & Hepatic failure & $\mathrm{N}$ \\
\hline & K92.9 & Disease of digestive system & $\mathrm{N}$ \\
\hline & R10.4 & Abdominal pain & $\mathrm{N}$ \\
\hline & R11.1 & Isolated nausea & $\mathrm{N}$ \\
\hline & R11.3 & Nausea with vomiting & $\mathrm{N}$ \\
\hline & R17 & Jaundice & $\mathrm{N}$ \\
\hline \multirow[t]{10}{*}{ Hemorrhagic } & D65 & Disseminated intravascular coagulation (DIC) & $\mathrm{N}$ \\
\hline & D68.9 & Coagulation defect & $\mathrm{N}$ \\
\hline & D69.6 & Thrombocytopenia & $\mathrm{N}$ \\
\hline & D75.9 & Blood disease & $\mathrm{N}$ \\
\hline & 162.9 & Intracranial hemorrhage (nontraumatic) & $\mathrm{N}$ \\
\hline & K92.0 & Hematemesis & $\mathrm{N}$ \\
\hline & K92.2 & Gastrointestinal hemorrhage & $\mathrm{N}$ \\
\hline & R04.0 & Epistaxis & $\mathrm{N}$ \\
\hline & R31.8 & Hematuria & $\mathrm{N}$ \\
\hline & R58 & Hemorrhage & $\mathrm{N}$ \\
\hline \multirow[t]{11}{*}{ Infectious } & A39.2 & Acute meningococcaemia & $\mathbf{Y}$ \\
\hline & A21.2 & Pulmonary tularaemia & $\mathrm{Y}$ \\
\hline & A00.0 & Cholera due to Vibrio cholerae 01, biovar cholerae & $\mathrm{N}$ \\
\hline & A00.1 & Cholera due to Vibrio cholerae 01 , biovar eltor & $\mathrm{N}$ \\
\hline & A00.9 & Cholera, unspecified & $\mathrm{N}$ \\
\hline & A01.0 & Typhoid fever & $\mathrm{N}$ \\
\hline & A01.1 & Paratyphoid fever A & $\mathrm{N}$ \\
\hline & A01.2 & Paratyphoid fever B & $\mathrm{N}$ \\
\hline & A01.3 & Paratyphoid fever C & $\mathrm{N}$ \\
\hline & A01.4 & Paratyphoid fever, unspecified & $\mathrm{N}$ \\
\hline & A02.0 & Salmonella enteritis & $\mathrm{N}$ \\
\hline
\end{tabular}


Appendix 2: Monitored discharge diagnoses with ICD-10 code from emergency departments, by category ${ }^{\mathrm{a}}$ (continued)

\begin{tabular}{|c|c|c|c|}
\hline Category & $\begin{array}{l}\text { ICD-10 } \\
\text { code }\end{array}$ & ICD-10 diagnosis & $\begin{array}{c}\text { Individual } \\
\text { analysis } \\
\text { done (Y/N) }\end{array}$ \\
\hline \multirow[t]{42}{*}{ Infectious (continued) } & A02.1 & Salmonella sepsis & $\mathrm{N}$ \\
\hline & A02.2 & Localized salmonella infections & $\mathrm{N}$ \\
\hline & A02.8 & Other specified salmonella infections & $\mathrm{N}$ \\
\hline & A02.9 & Salmonella infection, unspecified & $\mathrm{N}$ \\
\hline & A03.0 & Shigellosis due to Shigella dysenteriae & $\mathrm{N}$ \\
\hline & A03.1 & Shigellosis due to Shigella flexneri & $\mathrm{N}$ \\
\hline & A03.2 & Shigellosis due to Shigella boydii & $\mathrm{N}$ \\
\hline & A03.3 & Shigellosis due to Shigella sonnei & $\mathrm{N}$ \\
\hline & A03.8 & Other shigellosis & $\mathrm{N}$ \\
\hline & A03.9 & Shigellosis, unspecified & $\mathrm{N}$ \\
\hline & A15.0 & Tuberculosis of lung, confirmed by sputum microscopy with or without culture & $\mathrm{N}$ \\
\hline & A15.1 & Tuberculosis of lung, confirmed by culture only & $\mathrm{N}$ \\
\hline & A15.2 & Tuberculosis of lung, confirmed histologically & $\mathrm{N}$ \\
\hline & A15.3 & Tuberculosis of lung, confirmed by unspecified means & $\mathrm{N}$ \\
\hline & A15.4 & Tuberculosis of intrathoracic lymph nodes, confirmed bacteriologically and histologically & $\mathrm{N}$ \\
\hline & A15.5 & $\begin{array}{l}\text { Tuberculosis of larynx, trachea and bronchus, confirmed bacteriologically and } \\
\text { histologically }\end{array}$ & $\mathrm{N}$ \\
\hline & A15.6 & Tuberculous pleurisy, confirmed bacteriologically and histologically & $\mathrm{N}$ \\
\hline & A15.7 & Primary respiratory tuberculosis, confirmed bacteriologically and histologically & $\mathrm{N}$ \\
\hline & A15.8 & Other respiratory tuberculosis, confirmed bacteriologically and histologically & $\mathrm{N}$ \\
\hline & A15.9 & Respiratory tuberculosis unspecified, confirmed bacteriologically and histologically & $\mathrm{N}$ \\
\hline & A20.2 & Pneumonic plague & $\mathrm{N}$ \\
\hline & A36.0 & Pharyngeal diphtheria & $\mathrm{N}$ \\
\hline & A36.1 & Nasopharyngeal diphtheria & $\mathrm{N}$ \\
\hline & A36.2 & Laryngeal diphtheria & $\mathrm{N}$ \\
\hline & A36.3 & Cutaneous diphtheria & $\mathrm{N}$ \\
\hline & A36.8 & Other diphtheria & $\mathrm{N}$ \\
\hline & A36.9 & Diphtheria, unspecified & $\mathrm{N}$ \\
\hline & A40.9 & Streptococcal infection & $\mathrm{N}$ \\
\hline & A41.9 & Septicemia & $\mathrm{N}$ \\
\hline & A48.3 & Toxic shock syndrome & $\mathrm{N}$ \\
\hline & A49.9 & Bacteremia & $\mathrm{N}$ \\
\hline & A80.0 & Acute paralytic poliomyelitis, vaccine-associated & $\mathrm{N}$ \\
\hline & A80.1 & Acute paralytic poliomyelitis, wild virus, imported & $\mathrm{N}$ \\
\hline & A80.2 & Acute paralytic poliomyelitis, wild virus, indigenous & $\mathrm{N}$ \\
\hline & A80.3 & Acute paralytic poliomyelitis, other and unspecified & $\mathrm{N}$ \\
\hline & A80.4 & Acute nonparalytic poliomyelitis & $\mathrm{N}$ \\
\hline & A80.9 & Acute poliomyelitis, unspecified & $\mathrm{N}$ \\
\hline & A96.2 & Lassa fever & $\mathrm{N}$ \\
\hline & A98.0 & Crimean-Congo hemorrhagic fever & $\mathrm{N}$ \\
\hline & A98.3 & Marburg virus disease & $\mathrm{N}$ \\
\hline & A98.4 & Ebola virus disease & $\mathrm{N}$ \\
\hline & B03 & Smallpox & $\mathrm{N}$ \\
\hline
\end{tabular}


Appendix 2: Monitored discharge diagnoses with ICD-10 code from emergency departments, by category (continued)

\begin{tabular}{|c|c|c|c|}
\hline Category & $\begin{array}{l}\text { ICD-10 } \\
\text { code }\end{array}$ & ICD-10 diagnosis & $\begin{array}{c}\text { Individual } \\
\text { analysis } \\
\text { done (Y/N) }\end{array}$ \\
\hline \multirow[t]{3}{*}{ Infectious (continued) } & B34.9 & Viral infection & $\mathrm{N}$ \\
\hline & R50.9 & Fever & $\mathrm{N}$ \\
\hline & R57.2 & Septic shock & $\mathrm{N}$ \\
\hline \multirow[t]{3}{*}{ Opiod poisoning } & T40.1 & Poisoning: heroin & $\mathrm{N}$ \\
\hline & T40.6 & Poisoning: narcotics & $\mathrm{N}$ \\
\hline & F11.9 & Mental and behavioural disorders due to use of opioids & $\mathrm{N}$ \\
\hline \multirow[t]{31}{*}{ Neurological/muscular } & A05.1 & Botulism & Y \\
\hline & A39.0 & Meningococcal meningitis & $\mathbf{Y}$ \\
\hline & A86 & Viral encephalitis & $\mathrm{N}$ \\
\hline & A87.9 & Viral meningitis & $\mathrm{N}$ \\
\hline & F05.9 & Delirium & $\mathrm{N}$ \\
\hline & G00.9 & Bacterial meningitis & $\mathrm{N}$ \\
\hline & G03.9 & Meningitis, unspecified & $\mathrm{N}$ \\
\hline & G04.9 & Encephalomyelitis & $\mathrm{N}$ \\
\hline & G24.9 & Dystonia & $\mathrm{N}$ \\
\hline & G41.9 & Status epilepticus & $\mathrm{N}$ \\
\hline & G44.8 & Headache, other & $\mathrm{N}$ \\
\hline & G51.0 & Bell palsy & $\mathrm{N}$ \\
\hline & G52.9 & Cranial nerve disorder & $\mathrm{N}$ \\
\hline & G61.0 & Guillain-Barré syndrome & $\mathrm{N}$ \\
\hline & G62.9 & Polyneuropathy & $\mathrm{N}$ \\
\hline & G72.9 & Myopathy & $\mathrm{N}$ \\
\hline & G83.4 & Cauda equina syndrome & $\mathrm{N}$ \\
\hline & G83.9 & Paralytic syndrome & $\mathrm{N}$ \\
\hline & G93.4 & Encephalopathy & $\mathrm{N}$ \\
\hline & G95.9 & Myelopathy & $\mathrm{N}$ \\
\hline & G96.9 & Disorder of central nervous system, unspecified & $\mathrm{N}$ \\
\hline & H53.2 & Diplopia & $\mathrm{N}$ \\
\hline & M62.99 & Myopathy & $\mathrm{N}$ \\
\hline & R13.8 & Dysphagia & $\mathrm{N}$ \\
\hline & R26.88 & Abnormalities of gait and mobility & $\mathrm{N}$ \\
\hline & $\mathrm{R} 29.8$ & Symptoms and signs involving the nervous and musculoskeletal systems & $\mathrm{N}$ \\
\hline & R40.0 & Altered state of consciousness & $\mathrm{N}$ \\
\hline & R40.29 & Coma & $\mathrm{N}$ \\
\hline & R41.0 & Disorientation & $\mathrm{N}$ \\
\hline & R51 & Headache & $\mathrm{N}$ \\
\hline & R56.88 & Convulsions & $\mathrm{N}$ \\
\hline
\end{tabular}


Appendix 2: Monitored discharge diagnoses with ICD-10 code from emergency departments, by category ${ }^{\mathrm{a}}$ (continued)

\begin{tabular}{|c|c|c|c|}
\hline Category & $\begin{array}{l}\text { ICD-10 } \\
\text { code }\end{array}$ & ICD-10 diagnosis & $\begin{array}{c}\text { Individual } \\
\text { analysis } \\
\text { done (Y/N) }\end{array}$ \\
\hline \multirow{14}{*}{$\begin{array}{l}\text { Ophthalmological/ } \\
\text { otorhinolaryngological }\end{array}$} & $\mathrm{H} 16.0$ & Corneal ulcer & $\mathrm{N}$ \\
\hline & H10.9 & Conjunctivitis & $\mathrm{N}$ \\
\hline & H16.9 & Keratitis, unspecified & $\mathrm{N}$ \\
\hline & H18.9 & Disorder of cornea & $\mathrm{N}$ \\
\hline & H53.9 & Visual disturbance & $\mathrm{N}$ \\
\hline & H57.1 & Eye pain & $\mathrm{N}$ \\
\hline & H57.9 & Disorder of eye and adnexa & $\mathrm{N}$ \\
\hline & J02.9 & Acute pharyngitis & $\mathrm{N}$ \\
\hline & J03.9 & Acute tonsillitis & $\mathrm{N}$ \\
\hline & J04.0 & Acute laryngitis & $\mathrm{N}$ \\
\hline & J05.0 & Acute obstructive laryngitis (croup) & $\mathrm{N}$ \\
\hline & J05.1 & Acute epiglottitis & $\mathrm{N}$ \\
\hline & R07.0 & Pain in throat & $\mathrm{N}$ \\
\hline & S05.9 & Injury of eye and orbit & $\mathrm{N}$ \\
\hline \multirow[t]{18}{*}{ Respiratory } & J06.9 & Acute upper respiratory infection & $\mathrm{Y}$ \\
\hline & U04.90 & Severe acute respiratory syndrome (SARS) - suspected & Y \\
\hline & J04.1 & Acute tracheitis & $\mathrm{N}$ \\
\hline & $\mathrm{J} 04.2$ & Acute laryngotracheitis & $\mathrm{N}$ \\
\hline & J11.8 & Flu/influenza & $\mathrm{N}$ \\
\hline & J18.9 & Pneumonia & $\mathrm{N}$ \\
\hline & $\mathrm{J} 20.9$ & Acute bronchitis & $\mathrm{N}$ \\
\hline & J45.90 & Asthma & $\mathrm{N}$ \\
\hline & J69.0 & Aspiration pneumonia & $\mathrm{N}$ \\
\hline & J80 & Adult respiratory distress syndrome- ARDS & $\mathrm{N}$ \\
\hline & J96.0 & Acute respiratory failure & $\mathrm{N}$ \\
\hline & J98.0 & Bronchospasm & $\mathrm{N}$ \\
\hline & J98.9 & Respiratory disorder, unspecified & $\mathrm{N}$ \\
\hline & $\mathrm{R} 04.2$ & Hemoptysis & $\mathrm{N}$ \\
\hline & R05 & Cough & $\mathrm{N}$ \\
\hline & R06.0 & Dyspnoea & $\mathrm{N}$ \\
\hline & R06.1 & Stridor & $\mathrm{N}$ \\
\hline & R09.2 & Respiratory arrest & $\mathrm{N}$ \\
\hline \multirow[t]{11}{*}{ Systemic/dehydration } & E86.0 & Dehydration & $\mathrm{N}$ \\
\hline & E87.0 & Hypernatraemia & $\mathrm{N}$ \\
\hline & E87.1 & Hyponatremia & $\mathrm{N}$ \\
\hline & E87.6 & Hypokalemia & $\mathrm{N}$ \\
\hline & E87.8 & Disorders of electrolyte and fluid balance & $\mathrm{N}$ \\
\hline & N17.9 & Acute renal failure & $\mathrm{N}$ \\
\hline & $\mathrm{R} 23.0$ & Cyanosis & $\mathrm{N}$ \\
\hline & R53 & Malaise and fatigue & $\mathrm{N}$ \\
\hline & R55 & Syncope and collapse & $\mathrm{N}$ \\
\hline & R57.1 & Hypovolemic shock & $\mathrm{N}$ \\
\hline & R57.9 & Shock & $\mathrm{N}$ \\
\hline
\end{tabular}

